\section{JURNAL EKONOMI EFEKTIF}

ISSN : $2622-8882$, E-ISSN : 2622-9935

Jurnal Ekonomi Efektif, Vol. 3, No. 3, April 2021

@Prodi Manajemen Fakultas Ekonomi Universitas

Pamulang

\title{
PENGARUH PERPUTARAN PIUTANG TERHADAP RETURN ON ASSET PADA PT. SUMBER ALFARIA TRIAJYA TBK PERIODE 2013-2019
}

\author{
Agus Suhartono \\ Universitas Pamulang, Tangerang Selatan, Banten, Indonesia \\ dosen02498@unpam.ac.id
}

Manuskrip: Feb-2021 Ditinjau: Feb-2021; Diterima: Feb-2021; Online: Apr-2021; Diterbitkan: Apr-2021

\begin{abstract}
ABSTRAK
Penelitian ini bertujuan untuk mengetahui pengaruh Perputaran piutang terhadap Return On Asset pada PT. Sumber Alfaria Triajya Tbk Periode 2013-2019. Metode yang digunakan adalah explanatory research. Teknik analisis menggunakan analisis statistik dengan pengujian regresi, korelasi, determinasi dan uji hipotesis. Hasil penelitian ini variabel Perputaran piutang diperoleh nilai rata-rata sebesar 43,38\%. Variabel Return On Asset diperoleh nilai rata-rata $0,0626 \%$. Perputaran piutang berpengaruh positif dan signifikan terhadap Return On Asset dengan nilai persamaan regresi $\mathrm{Y}=0,015+0,001 \mathrm{X}$, dan nilai koefisien korelasi 0,893 atau memiliki tingkat hubungan yang sangat kuat dengan nilai determinasi 79,8\%. Uji hipotesis diperoleh signifikansi $0,000<0,05$.
\end{abstract}

\section{Kata Kunci: Perputaran Piutang, Return On Asset.}

\section{ABSTRACT}

This study aims to determine the effect of Accounts Receivable Turnover on Return On Assets at PT. Sumber Alfaria Triajya Tbk Period 2013-2019. The method used is explanatory research. The analysis technique uses statistical analysis with regression testing, correlation, determination and hypothesis testing. The results of this study, the receivable turnover variable obtained an average value of $43.38 \%$. The return on assets variable obtained an average value of $0.0626 \%$. Accounts receivable turnover has a positive and significant effect on Return On Assets with a regression equation value of $Y=0.015+0.001 X$, and a correlation coefficient value of 0.893 or has a very strong level of relationship with a determination value of $79.8 \%$. Hypothesis testing obtained a significance of $0.000<0.05$.

Keywords: Accounts Receivable Turnover, Return On Asset. 


\section{PENDAHULUAN}

\section{A. Latar Belakang Masalah}

Pada dasarnya setiap perusahaan baik yang bergerak di bidang dagang, jasa maupun manufaktur memiliki tujuan yang sama yaitu untuk memperoleh laba dan menjaga kesinambungan perusahaan di masa yang akan datang. Di eraglobalisasi saat ini, banyak sekali permasalahan yang timbul bagi manajemen suatu perusahaan didalam mengwujudkan usahanya dan menjalankan aktivitas perusahaan. Demi mempertahankan usahanya tersebut perusahaan hendaknya dapat memperoleh keuntungan atau laba yang maksimal dari setiap penjualan produk yang didapatkan.

Laba atau profit merupakan salah satu tujuan utama berdirinya setiap badan usaha. Tanpa diperolehnya laba, perusahana tidak dapat memenuhui tujuan lainnya seperti pertumbuhan yang terus menerus (going concern) dan tanggung jawab sosial (corporate social responsibility). Laba yang menjadi tujuan utama perusahaan dapat dicapai dengan penjualan barang atau jasa. Semakin besar volume penjualan barang atau jasa, maka laba yang dihasilkan oleh perusahaan juga akan semakin besar.

Secara umum, keberhasilan suatu perusahaan dalam menjalankan aktivitasnya seringkali didasarkan pada tingkat laba yang diperoleh. Sekali lagi, laba yang besar belum tentu menjadi ukuran bahwa perusahaan tersebut telah bekerja secara efisien. Tingkat efisiensi baru diketahui dengan cara membandingkan laba yang didapat dengan kekayaan atau modal yang menghasilkan laba tersebut (profitabilitas).

Profitabilitas merupakan salah satu aspek dalam menilai tingkat kesehatan perusahaan untuk mengetahui kemampuan perusahaan dalam memperoleh keuntungan atau laba. Menurut Riyanto, (2010) bahwa profitabilitas adalah "kemampuan perusahaan untuk menghasilkan laba selama periode tertentu". Sedangkan menurut Martono, dkk (2010) "Profitabilitas yaitu rasio yang menunjukan kemampuan perusahaan untuk memperoleh keuntungan dari penggunaan modalnya".

Lingkungan luar perusahaan ternyata juga turut adil berperan serta dalam proses pencapaian tujuan tersebut misalnya persaingan ekonomi, pesaing terus-menerus meningkatkan tanpa memperduliakan apakah para pelaku bisnis siap atau tidak. Kondisi pesaing yang semakin tajam inilah yang membuat banyak perusahaan tidak dapat menjual barang atau jasa dengan mudah. Dengan melihat kondisi ini, para pelaku bisnis sangat didesak untuk mencari upaya atau strategi dalam memenangkan pesaingan dan mencari posisi yang menguntungkan. Satu-satunya cara adalah dengan meningkatkan volume penjualan barang atau jasa.

Dalam upaya meningkatkan volume penjualan barang atau jasa suatu perusahaan sering menerapkan kebijakan penjualan kredit, disamping juga kebijakan penjualan tunai atau cash. Kebijakan penjualan kredit yang ditimbulkan oleh perusahaan ternyata menghasilkan piutang terhadap perusahaan. Menurut Dwi Martini, (2012) "Piutang merupakan klaim suatu perusahaan kepada pihak lain, pada umumnya akan berakibat adanya penerimaan kas dimasa yang akan datang". Masalah yang dihasilkan dari penjualan kredit tersebut juga ternyata tidak bisa diabaikan begitu saja karena resiko yang mungkin dihadapai oleh perusahaan yang berkaitan dengan piutang lebih besar dibandingkan jika perusahaan menjual barang atau jasa secara tunai.

Piutang merupakan salah satu elemen dalam modal kerja. Dengan kondisi tersebut, maka keadaannya selalu berputar. Dalam arti piutang akan tertagih pada waktu tertentu dan kemudian akan muncul lagi akibat penjualan kredit dan begitu seterusnya. Piutang akan tetap muncul selama perusahaan tetap melakukan kegiatan operasinya.

Tingkat perputaran piutang untuk setiap perusahaan juga dipengaruhi oleh periode perputaran piutang. Periode perputaran piutang ini tergantung dari panjang pendeknya 
ketentuan waktu yang ditetapkan perusahaan dalam syarat pembayaran kredit. Semakin lama syarat pembayaran kredit, maka semakin lama pula terikatnya elemen dari modal kerja tersebut dalam piutang dan hal ini berarti bahwa semakin rendah tingkat perputaran piutang dalam satu periode, begitu pula sebaliknya. Semakin cepat periode penagihan piutang berarti semakin tinggi tingkat perputaran piutang dan semakin tinggi pula tingkat laba yang akan mampu dihasilkan oleh perusahaan.

Maka dari itu, Selain besarnya jumlah piutang yang dimiliki, kecepatan kembalinya piutang menjadi kas juga sangat menentukan besarnya profitabilitas perusahaan. Kecepatan pelunasan piutang menjadi kas kembali ini disebut dengan perputaran piutang. Perputaran piutang tidak hanya digunakan untuk menilai kemampuan perusahaan dalam mengelola piutang secara efisien tetapi juga dapat digunakan sebagai media meningkatkan profitabilitas perusahaan.

Begitu pula dengan hambatan penagihan piutang itu sendiri sehingga pempengaruhi modal kerja perusahaan dan profit, seperti piutang tak tertagih akibat para pihak ketiga menunggak pembayarannya, fluktuasi jumlah saldo piutang perusahaan terhadap pendapatan yang diperoleh setiap tahunnya, masih belum sempurnanya ketentuan dan prosedur mengenai penagihan piutang oleh pihak perusahaan (collection) dan atau pelaksanaan pembayaran piutang oleh debitu.

Rasio Return On Asset (ROA) merupakan rasio yang menunjukan koefisiensian perusahaan dalam mengelola seluruh aktiva. ROA digunakan untuk mengukur tingkat pengembalian total aktiva setelah beban bunga dan pajak.

Melihat pentingnya perputaran piutang dalam mempengaruhi profitabilitas perusahaan, penulis tertarik mempelajari lebih dalam mengenai fenomena tersebut dengan membuat karya tulis dengan judul "Pengaruh Perputaran Piutang Terhadap Profitabilitas Perusahaan Pada PT. Sumber Alfaria Triajya Tbk.”.

\section{B. Rumusan Masalah}

1. Bagaimana Perputaran piutang pada PT. Sumber Alfaria Triajya Tbk Periode 20132019 ?.

2. Bagaimana Return On Asset pada PT. Sumber Alfaria Triajya Tbk Periode 2013-2019 ?.

3. Adakah pengaruh antara Perputaran piutang terhadap Return On Asset pada PT. Sumber Alfaria Triajya Tbk Periode 2013-2019?.

\section{Tujuan Penelitian}

1. Untuk mengetahui kondisi Perputaran piutang pada PT. Sumber Alfaria Triajya Tbk Periode 2013-2019.

2. Untuk mengetahui kondisi Return On Asset pada PT. Sumber Alfaria Triajya Tbk Periode 2013-2019.

3. Untuk mengetahui pengaruh antara Perputaran piutang terhadap Return On Asset pada PT. Sumber Alfaria Triajya Tbk Periode 2013-2019.

\section{METODE PENELITIAN}

\section{Populasi}

Populasi dalam penelitian ini laporan keuangan PT. Sumber Alfaria Triajya Tbk Periode 2013-2019 selama 8 tahun

\section{Sampel}

Teknik pengambilan sampling dalam penelitian ini adalah samplel jenuh, dimana semua anggota populasi dijadikan sebagai sampel. Dengan demikian sampel dalam 
penelitian ini laporan keuangan PT. Sumber Alfaria Triajya Tbk Periode 2013-2019 selama 8 tahun.

\section{Jenis Penelitian}

Jenis penelitian yang dipakai adalah asosiatif, dimana tujuannya adalah untuk mengetahui mencari keterhubungan antara variabel independen terhadap variabel dependennya

\section{Metode Analisis Data}

Dalam menganalisis data digunakan uji validitas, uji reliabilitas, analisis regresi linier sederhana, koefisien korelasi, koefisien determinasi dan uji hipotesis.

\section{HASIL PENELITIAN DAN PEMBAHASAN}

\section{Analisis Deskriptif}

Pada pengujian ini digunakan untuk mengetahui skor minimum dan maksimum skor tertinggi, ratting score dan standar deviasi dari masing-masing variabel. Adapun hasilnya sebagai berikut:

Tabel 1. Hasil Analisis Descriptive Statistics

\section{Descriptive Statistics}

\begin{tabular}{lr|r|r|r|r} 
& N & \multicolumn{1}{|c|}{ Minimum } & Maximum & \multicolumn{1}{c|}{ Mean } & Std. Deviation \\
\hline Perputaran piutang (X) & 8 & 28 & 60 & 43.38 & 11.686 \\
\hline Return On Asset (Y) & 8 & .04 & .08 & .0626 & .01443 \\
\hline Valid N (listwise) & 8 & & & & \\
\hline
\end{tabular}

Perputaran piutang diperoleh nilai minimum sebesar 28 dan nilai maximum 60 dengan rata-rata sebesar 43,38 dengan standar deviasi 11,686. Return On Asset diperoleh nilai minimum sebesar 0,04 dan nilai maximum 0,08 dengan rata-rata sebesar 0,0626 dengan standar deviasi 0,01443 .

\section{Analisis Verifikatif.}

Pada analisis ini dimaksudkan untuk mengetahui pengaruh variabel independen terhadap variabel dependen. Adapun hasil pengujian sebagai berikut:

\section{a. Analisis Regresi Linier Sederhana}

Uji regresi ini dimaksudkan untuk mengetahui perubahan variabel dependen jika variabel independen mengalami perubahan. Adapun hasil pengujiannya sebagai berikut:

Tabel 2. Hasil Pengujian Regresi Linier Sederhana

\section{Coefficients $^{\mathrm{a}}$}

\section{Unstandardized}

Coefficients

Standardized

Coefficients

\begin{tabular}{ll|r|r|c|c} 
Model & B & Std. Error & Beta & t & Sig. \\
\hline 1 (Constant) & .015 & .010 & & 1.458 & .195 \\
\hline Perputaran piutang (X) & .001 & .000 & .893 & 4.867 & .003 \\
\hline
\end{tabular}

Berdasarkan hasil pengujian pada tabel di atas, diperoleh persamaan regresi Y $=0,015+0,001 \mathrm{X}$. Dari persamaan tersebut dijelaskan sebagai berikut:

1) Konstanta sebesar 0,015 diartikan jika Perputaran piutang tidak ada, maka telah terdapat nilai Return On Asset sebesar 0,015 point.

2) Koefisien regresi Perputaran piutang sebesar 0,001, angka ini positif artinya setiap ada peningkatan Perputaran piutang sebesar 0,001 point maka Return On Asset juga akan mengalami peningkatan sebesar 0,001 point. 


\section{b. Analisis Koefisien Korelasi}

Analisis koefisien korelasi dimaksudkan untuk mengetahui tingkt kekuatan hubungan dari variabel independen terhadap variabel dependen baik secara parsial maupun simultan. Adapun hasil pengujian sebagai berikut:

Tabel 3. Hasil Pengujian Koefisien Korelasi Perputaran piutang Terhadap Return On

Asset.

\section{Correlations $^{b}$}

\begin{tabular}{llr|r} 
& & $\begin{array}{r}\text { Perputaran piutang } \\
(\mathrm{X} 1)\end{array}$ & \multicolumn{1}{c}{$\begin{array}{r}\text { Return On Asset } \\
(\mathrm{Y})\end{array}$} \\
\hline Perputaran piutang (X) & Pearson Correlation & 1 & $.893^{* *}$ \\
\cline { 2 - 4 } & Sig. (2-tailed) & & .003 \\
\hline Return On Asset (Y) & Pearson Correlation & $.893^{* *}$ & 1 \\
\cline { 2 - 4 } & Sig. (2-tailed) & .003 & \\
\hline
\end{tabular}

Berdasarkan hasil pengujian diperoleh nilai korelasi sebesar 0,893 artinya Perputaran piutang memiliki hubungan yang sangat kuat terhadap Return On Asset.

\section{c. Analisis Koefisien Determinasi}

Analisis koefisien determinasi dimaksudkan untuk mengetahui besarnya persentase pengaruh dari variabel independen terhadap variabel dependen. Adapun hasil pengujian sebagai berikut:

Tabel 4. Hasil Pengujian Koefisien Determinasi Perputaran piutang Terhadap Return

On Asset.

Model Summary

\begin{tabular}{ll|l|l|l} 
Model & R & R Square & Adjusted R Square & Std. Error of the Estimate
\end{tabular}

\begin{tabular}{lrrrr}
\hline 1 & $.893^{\mathrm{a}}$ & .798 & .764 & .00701 \\
\hline
\end{tabular}

Berdasarkan hasil pengujian diperoleh nilai determinasi sebesar 0,798 artinya Perputaran piutang memiliki kontribusi pengaruh sebesar 79,8\% terhadap Return On Asset.

\section{d. Uji Hipotesis}

Pengujian hipotesis dengan uji t digunakan untuk mengetahui hipotesis mana yang diterima. Rumusan hipotesis: Terdapat pengaruh yang signifikan antara Perputaran piutang terhadap Return On Asset.

Tabel 5. Hasil Uji Hipotesis Perputaran piutang Terhadap Return On Asset.

$$
\text { Coefficients }^{\mathrm{a}}
$$

$$
\begin{array}{c|c}
\text { Unstandardized } & \text { Standardized } \\
\text { Coefficients } & \text { Coefficients }
\end{array}
$$

\begin{tabular}{|c|c|c|c|c|c|}
\hline Model & B & Std. Error & Beta & $\mathrm{t}$ & Sig. \\
\hline 1 (Constant) & .015 & .010 & & 1.458 & .195 \\
\hline Perputaran piutang $(\mathrm{X})$ & .001 & .000 & .893 & 4.867 & .003 \\
\hline
\end{tabular}

Berdasarkan hasil pengujian pada tabel di atas, diperoleh nilai t hitung $>\mathrm{t}$ tabel atau $(4,867>2,447)$, dengan demikian hipotesis yang diajukan bahwa terdapat pengaruh yang signifikan atara Perputaran piutang terhadap Return On Asset diterima.

\section{PEMBAHASAN HASIL PENELITIAN}

\section{Kondisi Jawaban Responden Variabel Perputaran piutang}

Berdasarkan data empiris dan analisis data, variabel Perputaran piutang diperoleh nilai rata-rata per tahun sebesar 43,38. 


\section{Kondisi Jawaban Responden Variabel Return On Asset}

Berdasarkan data empiris dan analisis data, variabel Return On Asset diperoleh nilai rata-rata per tahun sebesar $0,0626 \%$.

\section{Pengaruh Motivasi Terhadap Kinerja Karyawan}

Perputaran piutang berpengaruh signifikan terhadap Return On Asset dengan persamaan regresi $\mathrm{Y}=0,015+0,001 \mathrm{X}$, nilai korelasi sebesar 0,893 atau memiliki hubungan yang sangat kuat dengan kontribusi pengaruh sebesar 79,8\%. Pengujian hipotesis diperoleh nilai $t$ hitung $>\mathrm{t}$ tabel atau $(4,867>2,447)$. Dengan demikian hipotesis yang diajukan bahwa terdapat berpengaruh signifikan antara Perputaran piutang terhadap Return On Asset diterima.

\section{PENUTUP}

\section{Kesimpulan}

a. Variabel Perputaran piutang diperoleh ratting score sebesar 43,38 berada di rentang skala 3,40 - 4,19 dengan kriteria baik atau setuju.

b. Variabel Return On Asset diperoleh ratting score sebesar 0,0626 berada di rentang skala 3,40 - 4,19 dengan kriteria baik atau setuju.

c. Perputaran piutang berpengaruh signifikan terhadap Return On Asset dengan persamaan regresi $\mathrm{Y}=0,015+0,001 \mathrm{X}$, nilai korelasi sebesar 0,893 atau sangat kuat dan kontribusi pengaruh sebesar 79,8\% sedangkan sisanya sebesar 57,9\% dipengaruhi faktor lain. Uji hipotesis diperoleh nilai t hitung > t tabel atau $(4,867>2,447)$.

\section{Saran}

a. Diharapkan dengan penelitian ini akan memberikan gambaran kepada masyarakat mengenai kondisi keuangan PT Sumber Alfaria Trijaya, Tbk agar menjadi pertimbangan dalam menanamkan investasi saham.

b. PT. Sumber Alfaria Trijaya, Tbk hendaknya memperhatikan perputaran piutang pada perusahaan serta menganalisis rasio keuangan yang berhubungan dengan profitabilitas, karena besarnya Profitabilitas yang di peroleh dan dikelola perusahan menentukan tingkat perkembangan atas aset yang dilakukan.

c. Saran bagi peneliti selanjutnya diharapkan menggunakan obyek yang luas dengan perpanjang periode penelitian dan menambah perusahaan yang ada dalam satu sub sektor agar semple yang diperoleh akan lebih akurat. Penguji.

\section{DAFTAR PUSTAKA}

Agus Harjito \& Martono, (2010) "Manajemen Keuangan” Yogyakarta: Penerbit Ekonisia. Agus Sartono. (2010). "Manajemen Keuangan Toeri dan Aplikasi", Edisi keempat, Yogyakarta: Penerbit BPFE.

Algifari. (2015). “Analisis Regresi untuk Bisnis dan Ekonomi”. Yogyakarta: BPFE.

Amelia, R. W., \& Sunarsi, D. (2020). Pengaruh Return On Asset Dan Return On Equity Terhadap Debt To Equity Ratio Pada PT. Kalbe Farma, TBK. Ad-Deenar: Jurnal Ekonomi dan Bisnis Islam, 4(01), 105-114.

Arikunto, Suharsimi (2014). "Prosedur Penelitian Suatu Pendekatan Praktek". Jakarta: Rineka Cipta.

Bambang Riyanto, (2011). "Dasar-dasar Pembelanjaan Perusahaan". Edisi ke empat, BPFE Yogyakarta.

Dwi, Martani, dkk. (2012).“Akuntansi Keuangan Menengah Berbasis PSAK”.Buku 1,Jakarta, Salemba Empat 
Fahmi, Irham (2012), "Pengantar Manajemen Keuangan” Cetakan pertama. Bandung: Penerbit Alfabeta.

Haque, M. G., Nurjaya, N.,Affandi, A., Erlangga, H., \& Sunarsi, D. (2021). Micro Financial Sharia Non-bank Strategic Analysis: a Study at BMT Beringharjo, Yogyakarta. Budapest International Research and Critics Institute (BIRCI-Journal): Humanities and Social Sciences, 4(2), 1677-1686.

Imam Ghozali (2017). “Aplikasi Analisis Multivariate Dengan Program SPSS”. Edisi Kelima. Semarang: Badan Penerbit Undip.

J Supranto, 2001, "Statistik teori dan aplikasi",cetakan kedua,Jakarta:Penerbit Erlangga.

Jasmani, J. (2018). Pengaruh Kinerja Keuangan Terhadap Harga Saham (Analisis Pada Perusahaan Property dan Real Estate Yang Go Public di Bursa Efek Indonesia. Jurnal Akuntansi Indonesia, 12(2).

Jasmani, J. (2019). The Effect of Liquidity and Working Capital Turnover on Profitability at PT. Sumber Cipta Multiniaga, South Jakarta. PINISI Discretion Review, 3(1), 29 38.

Kasmir (2010), “Analisis Laporan keuangan”, penerbit raja grafindo persada, Jakarta

Kasmir, (2010). "Pengantar Manajemen Keuangan", Edisi Pertama, Cetakan kedua, Jakarta: Penerbit Prenada Media.

Kasmir. (2012) "Pengantar Manajemen Keuangan", Edisi Pertama, Cetakan kedua, Jakarta: Prenada Media.

Kuncoro,Mudrajad dan Suhardjono,2012,“manajemen perbankan Teori dan aplikasi”Edisi 1,BPEE,Yogyakarta

Lukman Syamsudin. 2007. "Manajemen Keuangan Perusahaan". Jakarta: RajaGrafindo Persada

Martono dan Agus Harjito, (2011). "Manajemen Keuangan”, Jakarta: Penerbit Ekonisia..

Munawir (2010), “Analisis Laporan Keuangan”, Edisi Ke Empat, Penerbit Liberty, Yogyakarta.

Murtie, Afin, 2015, Bisnis Tahan Banting Sambut MEA. Klaten : Cable Book

Noryani, Y. B. G., Sari, W. I., Rosini, I., Munadjat, B., Sunarsi, D., \& Mahnun Mas' adi, G. (2020). Did ISO 45001, ISO 22000, ISO 14001 and ISO 9001 Influence Financial Performance? Evidence from Indonesian Industries. PalArch's Journal of Archaeology of Egypt/Egyptology, 17(7), 6930-6950.

Pujiati, H., Sunarsi, D., Affandi, A., \& Anggraeni, N. (2021). Effect of ISO 9001: 2015 Quality Management Implementation in Education on School Performance. Journal of Contemporary Issues in Business and Government, 27(1), 1848-1855

S.munir, 2007.“Analisa Laporan keuangan”. Yogyakarta : Leberty.

Santoso, Singgih (2015). "Menguasai Statistik Multivariat". Jakarta: PT Elex Media Komputindo.

Sartono, "Manajemen Keuangan Aplikasi Dan Teori”, Edisi Keempat, BPFE, Yogyakarta, 2008.

Sawir, (2003). “Analisis Kinerja Keuangan dan Perencanaan Keuangan Perusahaan”, Cetakan ketiga, Jakarta: Penerbit PT. Gramedia Pustaka Utama.

Sugiyono (2017), "Metode Penelitian Administrasi : dilengkapi dengan Metode R \& D". Bandung: Alfabeta.

Suhartono, A., Jati, W., \& Sunarsi, D. (2019). Pengaruh Earning Per Share Dan Return On Asset Terhadap Harga Saham Pada PT. Bank Negara Indonesia Tbk Periode 20092018. Jurnal Manajemen, Bisnis dan Organisasi (JUMBO), 3(3), 182-194. 